\title{
W zwierciadle obcej literatury (recepcja Zbigniewa Herberta w Niemczech)
}

Katarzyna Krasoń 


\section{Katarzyna Krasoń}

\section{W zwierciadle obcej literatury (recepcja Zbigniewa Herberta w Niemczech)}

$\mathrm{K}$ arl Dedecius uważa autora Rovigo za jednego z najlepszych poetów powojennych w Europiel. Podkreśla, że Herbert oprócz Wisławy Szymborskiej i Tadeusza Różewicza, a także Stanisława Lema i autora Ferdydurke - odniósł sukces w krajach niemieckiego obszarı językowego i poza jego granicami (1)PR, s. 592). Także Walter Höllerer, będący entuzjastą dorobku pisarskiego polskiego autora, wyraża się o I lerbercie jako o „wielkim poetyckim odkryciu”". A Gisela Högensberg pisze, że utwory autora Studium przedmiotu

' Zob. K. Dedecius, Panorama der polmischen Literatur des 20. Jahhlunderts. Ein Rundblick, t. 7. Zürich 2000), s. 592 (dalej cyt.: DPR).

2 W. I Iöllerer. Theorie der modernen Lyrik. Dokmmente =ur Poctik, wyd. N. Miller. I I. I lartung. t. 2, München 2003, s. 749 (dalej cyt.: HTML). Tego samego zdania jest Ulrike Jekutsch (U. Jekutscl, Die Übersetzm!s

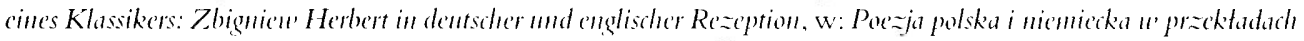

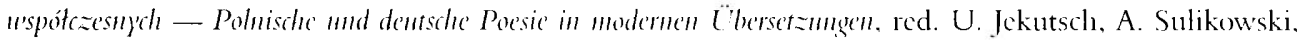
Szczecin 20(02, s. 173; dalej cyt.: UJZF1). Ernst Gïnther Bleisch zarytuowal swój artykut: Tón Polık po-

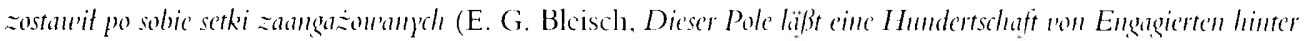
sidh, "Münchener Merkur”, 3 II 1968). Jednak nic na ostanim z wymienionych krytykow albo Dedeciusic i Höllererze kończy sį̣ zainteresowanic osobą i twórczością 1 lerberta w krajach niemieckiego obszaru językowego. Należaloby jeszcze wymienić Alberta, który nazywa wiersze autora Vipisu „prawdziwymi klcjnotami” (..Rhein-Neckar-Zcitung", 18 1 1965, s. 3). W podobnym duchu pisze Franz Theodor Csokor. Fascynuje go w lirykach polskicgo autora „duchowa przejrzystośc”. której jego zdaniem nie zauvaża siç w liryce światowcj (..Neuc Züricher Zeitung”, 2I IV 1966, s. 2). Stwicrdza, że wiersze Herberta nożna

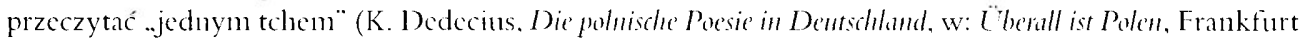
am Main 1974, s. 99). Uznanie dla autora Pana Cogito okazal takze Werner Schenk w audycji radiowej Przegląd ksiazik. nadanej przez rozglośniç Berlina Zachodnicgo 7 kwietnia 1965. 
odpowiadają odczuwaniu świata przez Niemców ${ }^{3}$. Recenzje oraz rozprawy naukowe na temat Herberta zazwyczaj nie zawierają wnikliwych interpretacji jego utworów, które mogłyby być „dopełnieniem” dotychczasowego stanu badań w Polsce. Fragmenty wybranych recenzji oraz opracowań twórczości autora Strumy śutatta przytaczam w pierwszej części niniejszego szkicu: Cźytanie Herberta "'Niemczech. Zauważa się w nich - podkreśla Jekutsch - „dodawanie” poecie coraz to innych "etykietek" (UJZH, s. 179), co wprawdzie świadczy o popularności polskiego autora, ale jednocześnie wskazuje na powierzchowną lekturę jego utworów i postrzeganie go poprzez stereotypy ${ }^{+}$. Niemieccy literaturoznawcy zwracają uwagę, że wlaśnie za naszą zachodnią granicą stworzono I Herbertowi odpowiednie warunki, umożliwiające mu artystyczny rozwój. Świadczy o tym na przykład wypowiedź Dedeciusa, który podkreśla, że poeta, należący do rodziny, której drugim językiem, ulatwiającym wzajemną komunikację, byl niemiecki, zostal odkryty i należycie

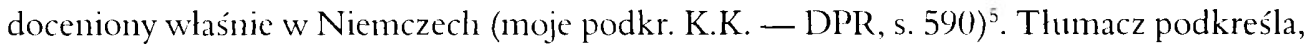
że „październikowa odwilz” umożliwiła Herbertowi zaskoczenie publiczności literackiej znakomitym debiutem poetyckim, jakim był zbiorek liryczny Struna śuiatła (1956), shużacy oświeceniu zdezorientowanego narodı, który przeżyl okupację hitlerowską oraz okres stalinizmu (DPR, s. 571).

${ }^{3}$ Zob. „Bücherci und Bildung” R. 17: 1965. z. 1, s. 14. Więcej przykładów wypowiedzi niemieckich badaczy literatury, którzy manifestują swój zachwyt nad twórczością l lerberta. podaję w pracy poświçconej przekładom baśni. a wlasciwic ,anty-baśni“ autora Rorigo - zob. K. Krasoń. Baśí " przektadzic (O na-

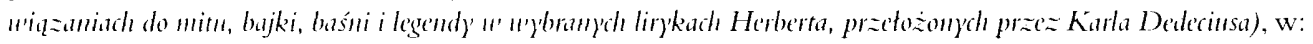
Baru'y'śu'iata báśni. red. U. Chęciníska, Szczecin 2003, s. 150-151. przyp. 7.

' Kazimicrz Bartoszyński slusznic uważa, iz stereotyp jest niczbędıy w spoleczncj komunikacji (Zagudnie'-

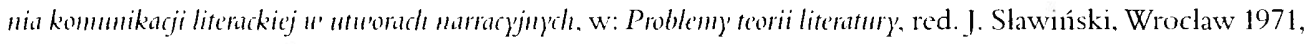
s. 128-1+5. Por.: Z. Mitosek. Literatura i stcreotypy. Wroclaw 1974: A. Schaff, Stereotypy a dziatanic ludzkic, Warszawa 1981.

${ }^{5}$ Do listy nagród, którymi obdarowano poctç za granicą, nak żałoby jeszcze dodać następujące: Berhlen-Préis (1987); nagroda im. Brunona Schulza. ufundowana przez amerykańską Fundację Studiów Polsko-Żydowskich $i$ amerykaniski l'EN-Club (1988): nagroda miasta Jcrozolimy (1990); nagroda radia niemicckiego (Preis der Sïdwestfunk-Büdher-Bestenliste, 1994); Europejska Nagroda Poetycka miasta Münster (1997); nagroda im. T. S. Eliota amerykańskicj Fundacji Ingersol (1995). Herbert otrzymał także — razem z jego pierwszym nicmicckim thumaczem Karlem Dedeciusem - Nagrodę in. Samucla Bogumila Lindego miast partnerskich Getyngi i Tortunia (1997). Nakezal także do trzech nicmieckich akademii: w Monachium. Berlinic i Darmstadzic. W 1966 roku stal się korespondencyjnym członkicm Bawarskicj Akadomii Sztuk Piçknych. Katarzyna Herbert, wdowa po poecic. wyznaje: „Dostal (...) w Nicmezech Nagrodę Lenaua. Ponadto w jakimś polskim leksykonic napisali późnicj. że była to Nagroda Lenina. Zbyszka to bardzo bawiło. Nic prostowal. Mówil "Niech sį̣ mnic trochę boją" (rozmowa Jacka Żakowskicgo z Katarzyną Herbert, „Gazeta Wyborcza”, 30 XII 2000) - I I 20(0) I). Z okazji przyznania Herbertowi nagrody Gottfrieda von Herdera (1973) prof. Manfred Mayerhofer wyglosil mowę laudacyjn̨̧. w którcj podkreślal gł̧̨boki humanizm poczji l lerberta (DPR, s. 587). Wypowiedź Mayerhofera przytacza Dedecius także w rozdziale Zbignnieu' Herbert swojej pracy Poetik der Pole't. Fromkfurter lorlesungen. Frankfurt an Main 1992, s. 80. 
W kolejnej części artykułu dokonuję ustaleń metodologicznych, które okazują się przydatne w zaproponowanych w części trzeciej analizach dwóch przekładów wierszy Herberta: Nike, wenn sie zögert" (Nike która się "waha ) Dedeciusa oraz Abschied vom September (ZI IPa, s. 26-27) - Pożegnanic urześnia (Sś, s. 8) Jöhlinga. Pierwszy z wymienionych utworów należy do często omawianych w Niemczech, bowiem poeta nawiązuje w nim zarówno do czasów wojny i okupacji. jak i do tradycji europejskiej (grecki antyk). Drugi, także odwołujący się do wydarzeń z lat 1939-1945, wzbudził wprawdzie muiejsze zainteresowanie niemieckicj publiczności literackiej, ale jego thumaczenie jest tutaj przedmiotem analizy, ze względu na zaskakujące wybory środków stylistycznych, dokonane przez Jöhlinga, będące wyrazem jego interpretacji wiersza I Ierberta.

Zamierzam pokazać, że zarówno Dedeciusowi, jak i Jöhlingowi, którzy świadomie zrezygnowali z przekładów doslownych, udalo się nie tylko oddać sensy literackich pierwowzorów, ale także „wyczarować” piçkne światy poetyckie. Wybór wskazanych thumaczeń nie jest przypadkowy, ponieważ na ich przykładzie chcę dowieść, że niezależnie od tego, czy wykreowany przez thumacza obraz naśladuje ${ }^{\text {' }}$ znany z oryginału wizerunek poetycki (Dedecius), czy też znacznie od niego się różni (Jöhling), może oddawać sens tekstu pierwotnego. Celem pracy jest zdanie sprawy z konk retyzacji dwóch wspomnianych liryków Herberta. Teoria konkretyzacji — pisze Glowiński —

nakłada się na wszystkic tendencje, które w analizic utworu biorą pod uwagę obecność czytelnika i zastanawiają się nad wyznaczoną mu rolą. Ujawnić może ona swą wagę zarówno w interpretacjach poszczególnych utworów, dokonywanych ze względu na wyznaczoną w nich rolę czytelnika, jak téz w analizie tego, co nazywa się „życiem” dzieła literackiego".

Rezygnıję z badań statystycznych, mających na celı sprawdzenie zainteresowania osobą i twórczością poety u naszych zachodnich sąsiadów. Nie zajmuję się również dialogiem tekstowym, na przyklad nawiązaniami poetów niemieckich do twórczości I Ierberta i odwrotnie. Wnioski dotyczące recepcji poety wysmuwam wyłącznie na podstawic analizy porównawczej tłumaczeń z ich oryginalami. Odnoszę omawiane tutaj przeklady do wypowiedzi o I Ierbercie ich autorów oraz niemieckich literaturoznawców, co - zgodnie z su-

"Zob. Zbignicu Herbert. Poesicalbum 86, wyb. i wyd. B. Jentzsch, tl. K. Dedecius, B. Jentzsch. W. Jöhling. R. Kirsch, H. Olscliowsky. Berlin (I)DR) 1974, s. 5-6 (dalej cyt: ZI IPa).

Z Zob. Z. Herbert, Struma śu'virta, Warszawa 1956, s. 73-74 (dalej cyt.: Sś).

${ }^{8}$ Naśladownictwo traktıję - za Marią Renatą Maycnową - jako tworzenic przez tłumacza rzeczywistości literackicj, która nie jest odzwierciedleniem literackicgo pierwowzorm. lecz jego znakiem ikonicznym

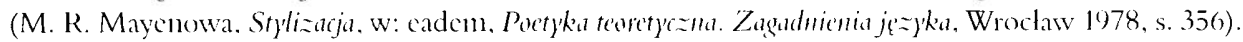

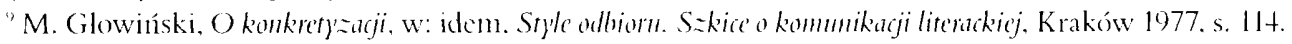


gestią Glowińskiego ${ }^{10}$ - umożliwia mi pokazanie, jak przywołani tłumacze przyglądają się sobie - cytuję Dedeciusa — „w zwierciadle obcej literatury"

\section{Czytanie Herberta w Niemczech (krótki przegląd)}

Za naszą zachodnią granicą często podkreśla się powściągliwość Herberta w wyrażaniu uczuć i emocji w jego dziełach, bowiem autor Struny' śviatta szansę realizacji odwiecznego marzenia poety, że jego twórczość będzie czytana przez następne pokolenia, widzi w zerwaniu więzów między autorem a dzielem ${ }^{12}$ — na przykład Walter I Ölleler pisze o Herbercie:

Zbigniew Herbert nie lubi u wspólczesnych artystów zainteresowania własną osobą: „moim marzeniem jest anonimowa twórczość, wyznał w jednym z wywiadów. Ze względu na to, że wspomniana „anonimowośc” nie jest już dzisiaj osiągalna, poeta najchętniej wypowiada się poprzez maski (HTML, s. 749) ${ }^{13}$.

W tym samym duchu wyraża się Karl Dedecius, który akcentuje, że Herbert konsekwentnie realizuje w swej twórczości postulat Flauberta: „poeta powinien ukryć się w swym dziele tak, jak stwórca ukrywa się w naturze" (DPR, s. 581). Dedecius i Höllerer traktują wyznanie poety jako artystyczne credo autora Struny śuriatta, dla którego rzeczywistość wyrażona w języku, tracąc związek z empirycznie sprawdzalnym konkretem, traci także moc prawdziwości. Podkreślają, że pisanie nie jest dla Herberta profesją, lecz powołaniem, które

I" Zob. op. cit.. s. 11t. Należy podkreślić. że praktyczna realizacja postawionego tutaj celu wymaga ponickąd ode muic ..wpisania siç" w rolę adresatów przekładı. W podejmowanych przeze mnie próbach identyfikacji z niemicckin czytchikiem, z którego perspektywy analizuję wybrane tlumaczenia liryków I terberta, pomocne okazaly siç uwagi Hansa-Georga Oertgena, germanisty i teologa z Kaiscrslautern.

${ }^{11}$ K. Dedecius. Polıcy i Niency. Postumicturo ksiqziek. Kraków 1972, s. 114. Wykluczam z obszaru mych zainteresowaí trzecic i piąte świadectwo odbioru: 3. teksty odwolujące się do innych tekstów przez swoja strukturę (pastisze, parodic, stylizacje, itp.): 5. badania socjologiczne o charakterze empirycznym, zajmujạce siç cyrkulowaniem dzicł literackich wśród różnych grup społecznych i waściwymi im sposobami lektury. Interesują mnic w ninicjszej pracy tylko trzy świadectwa odbioru: 1. wypowiedzi (literackie, paralitcrackic, krytycznc), w których sam proces lcktury nic podlegl tematyzacji; 2. wypowiedzi meta-literackic o clarakterze dyskursywnym (krytyczne. historycznoliterackic, teoretyczne itp.), w których czynność lektury zostala stematyzowana: 4. transformacje dokonywane na dzick literackim: przcklady (M. Glowiń-

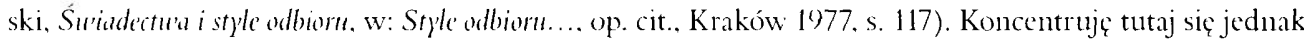
na przckladach.

12 Zob. K. Dedecius, O Polse, Europie, literatura', Wroclaw 1996, s. 47.

1.3 Warto dodać. że w drugim tomic przywolancj tu pracy I Iöllerera nazwisko polskicgo pocty pojawilo siç obok takich wybitnych nazwisk z różnych kręgów geograficznych i cpok, jak Celan. Heißenbüttcl, Jandl, Commringer. Trakl, Rilke. a takze T. S. Eliot i F. G. Lorca. (Wszystkic thumaczenia wypowiedzi niemieckich literaturoznawców moje - K. K.). 
polega na kwestionowaniu pozornej pewności mitów w celu dotarcia do prawdy etycznej $\left(\right.$ AdPh, s. 249) ${ }^{14}$. Widzą w nim ironizującego klasykal5 i poetę-moralistę, nawiązującego do europejskiej tradycji kulturowej, a zarazem głęboko zanurzonego w historii narodu polskiego. Dedecius ıważa wiersze I Ierberta - jak wyraził się przywolany tłumacz - za ,wzorcowy przykład owocnej syntezy tradycji wiersza polskiego i współczesnej liryki światowej " ${ }^{\prime \prime}$. Zatem autor Struny' śu'iatta uważany jest w Niemczech - tak jak na przyklad w Polsce i krajach anglojęzycznych - za poetę e uropejskiego ${ }^{17}$, który nawiązuje do mitologii klasycznej oraz systemów filozoficznych, znanych w kręgu kultury basenu Morza Śódziemnego. Dostrzega się także w jego utworach polskie „klimaty”, jak mit dzieciństwa i rodziców czy téz - często powracający w takich tomach, jak choćby Struma suriatta (1956) i Hermes, pies i guriazda (1958) ${ }^{\text {ix }}$ - motyw pamięci o of iarach faszyzmu. Dedecius pisze, iz debiutancki zbiorek liryczny I lerberta

zaczyna się wszakże od wspomnień z dziecinistwa, które „zamurzają się” w ciemnościach: elegie i epitafia, które poświęcone są (...) ofiarom wojny, a także minionym światom i „umarłym religion”. Ważny to temat w latach powojennych, ale... za chwilę zaczyna się „Uprawa filozofii”, rozmowa z Markiem Aurelim (...) i rewizja mitologii (1)PR, s. 571).

Warto wspommieć, że w bylej NRD autor Raportu z oblężnego miasta traktowany byl jako poeta socjalistyczny (zwraca na to uwage Jekutsch, UJZH, s. 185). Przykładowo Heinrich Olschowsky pisal: „Uniwersalizm poezji Herberta świadczy o suwerenności tej liryki, także wówczas, gdy poeta wiąze kwestic wlasnego socjalistycznego rozwoju z prasta-

${ }^{1+}$ Zob. K. Dedecius, O Polsce.... op. cit. Z utworów I Ierberta, który podaje w wątpliwość wszelkie ideologie, wynika, że to, co nic jest empirycznic sprawdzalne, jest nicludzkic. martwe i puste: ..wymyślitem w końcu slowo byt / slowo twarde i bezbarwne / trzeba dlugo rękami rozgarniać cieple / liścic/ trzeba podeptać obrazy / zachód stońca nazwać zjawiskicm / by pod tym wszystkim odkryé / martwy bialy/filozoficzny kanicń” (Z. Herbert, L'prulu'a filozofiii, Sś, s. 51).

1. Przykladowo l'cter Handtke wyrazil podziw dla .ironiczncj, swobodnic żywej poczji I Ierberta" (..Österreichischer Rundfunk", (Graz, 31 V 1965. s. 5).

1"Z. Herbert: Gedichte, tl. i posl. K. Dedecius, Frankfurt an Main 196t, s. 591 (dalej cyt.: ZI IG). W immej pracy Dedecius pisze, że historia, do którcj nawiązuje w swych utworach Herbert. jest przez poctę na nowo interpretowana, ,a przez to calkowicie teraźnicjsza” (DPR. s. 592). Zdaniem Wolfganga Krausa. znaczenia pocty należy upatrywać w ty'n, że w jego utworach kulturowa kontynuacja jest obecna - cyttję tlumacza - w .przeżyciu dzisiejszego czasu” (..1)ic Presse”. 23-2+ XI 1974. s. 4).

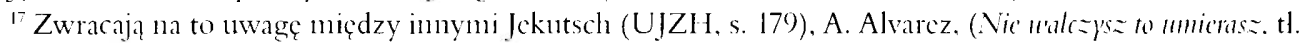
z ang. M. Iteydel, ..Kontrapunkt" 1999, 11 1-2) oraz Bogdana Carpenter (Zbignicha Herberta lekeja s=tuki. tl. $z$ ang. A. Szostkicwicz, op. ct.).

${ }^{18}$ Zob. Z. Herbert. Hermes, pies i gul'iazda. Warszawa 1958 (dalej cyt.: I Ipig). 
rymi wzorami historii ludzkości i jej kultury" (OFLM, s. 186) ${ }^{19}$. W tomie Poesiealbum 86 zostaje pomieszczony lakoniczny komentarz wspomnianego tlumacza do twórczości lirycznej Herberta, w któryın poeta charakteryzowany jest jako „wyróżniające się zjawisko poetyckie w Polsce Ludowej” (ZHPa, s. 9). Tłumacz zarówno we wcześniej przywołanej pracy Lyrik in Polen („Liryka w Polsce”), jak i we wspommianym komentarzu akcentuje, że „socjalistyczna liryka I Ierberta” uczy - cytıję badacza - „krytycznego spojrzenia na naszą teraźniejszość okiem starych mędrców" (ZI IPa, s. 9). Inne uzasadnienie dla występujących w wierszach poety odwołań do źródeł kultury europejskiej znajdują Kneip i Dedecius, którzy uważają, że poetycki świat I Ierberta zaskoczył powojennych czytelników, przyzwyczajonych do - cytuję autora Ost-West Basar — „literacko spłyconych stalinowskich eksperymentów” (DPR, s. 575). Ów świat tworzony jest w oparciu o mit, który ulega w dziełach poety demitologizacji, co thumacz eksponuje w dokonanych przez niego przekładach ${ }^{20}$.

Z dotychczasowych rozważań wynika, że Herbert jawi się z jednej strony — jeszcze raz mocno podkreślam - jakoklasyk, moralista i filoz of (RFN), z drugiej jednak jako autor, który akceptuje socjalistyczny ustrój (NRD) ${ }^{21}$. Abstrahując od tego, na jaką z „etykietek”, przypisywanych w Niemczech poecie, zgodzimy się, Herbert — podkreśla Michael Krüger - należy do nielicznych, którym udało się stworzyć „poezję uniwersalną", wzbudzającą zainteresowanie czytelnika niezależnie od tego, z jakiego kraju pochodzi i jakim językiem się posługuje ${ }^{22}$. Z tego whaśnie powodu znalazł poeta w krajach niemiec-

"Olschowsky wypowiada siç w taki sam sposób o Rożewiczu (H. Olschowsky. Funktionsu'andel der Lyrik seit Mitte der fiunfziger Jahre. w: idem, Lyrik in Polen. Strukturen und Traditionen im 20. Jahshumdert, Literatur und Gesellschaff. Berlin (DDR) 1979, s. 186 (dalej cyt.: OF.LM). Zob. tez: idem, Das .Ähnliche und das andere, w: Polnische Literutur in der Bundescenblik. Die Rezeption der polnischen Literatur im deutschsprachigen Raum und der dentschsprachigen in Pole'n (1945-1985), wyd. H. Kncip, H. Orlowski, red. J. Wierczimok. Darmstadt 1988. s. 41-7+ (dalej cyt.: HKB).

2" Zob. H. Kncip. "Bollherke gegen die Barburei der Geschichte...". Polnische Literatur in der Bundesrepublik, w: HKB, s. 26.

${ }^{21}$ W ten sposób - powszechnic wiadomo - czytano w NRI) utwory wszystkich polskich poctów powojennych, a także weześniejszych. Trwało to do czasu obalenia Muru Bcrlińskicgo w noc sylwestrową 1989 roku. Olschowsky'cgo również cechowal w owych czasach - stosuję określenie tłumacza - .ideologiczny wzorzec odbioru”. Thumacz pisze po latach, że przywolany wzorzec odwolywal się „do systemu idei i poglądów, charakterystycznych dla określonej grupy spoleczncj, systenu zorientowanego nie tyle na analiz̨̧ rzeczywistości według kryterium prawdy i falszu, co na potwierdzenie tożsaności dancj grupy, uzasadnienic jej pozycji spoleczno-polityczncj i obronç jej interesów. Litcratura traktowana ideologicznic to instrument propagandy. Założony z góry odbiór litcratury można nazwać «zdradą ideologiczną". Nie zależy mu na różnorodnym odbiorze czytelniczym, chee zapobice takicj aktualizacji znaczeń utworu, która zaklócałaby jednorodną, przed-

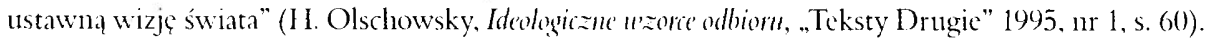

2" Zob. Z. Herbert. Das Land made dem ich mich selme. L.trik and Prosa, tl. G. von Birkenfeld, K. Dedecius, K. Staemmler. O. J. Tauschinski. W. Ticl. wyb. i przed. M. Krüger, posl. J. Bloński, Frankfurt an Main 1987, s. 9 (dalej cyt.: Ls). Tego sanego zdania jest Reinhard Lauer (Der Didher und sein Dicherr..., „Göttinger Jahrbuch" 1997, nr 45, s. 203). Do informacji, że czytelnik wierszy Herberta jest traktowany przez autora jako godny partucr ..rozmowy”, można dotrzé przez internetową stronę polskicj ambasady w Nienczech (http://www.botschaft-polen.de/literatur/herbert.html). 
kiego obszaru językowego - przypominam słowa autora Polnische Profile - szeroką rzeszę wiernych czytelników (breite und trene Gemeinde - 1)PR, s. 59()).

Warto dodać, że Dedecius jest największym popularyzatorem poezji I lerberta w Niemczech, a Bereska, Staemmler i Tiel oraz Tauschinski thumaczyli zazwyczaj jego eseje i dramaty $^{23}$. Późniejsze zbiorki liryczne: Raport z oblęzonego miasta (1983) i Rovigo (1992) przekładają Oskar Jan Tauschinski i Klaus Staemmler ${ }^{2+}$. Dedecius jest do $197+$ roku jedynym tłumaczem liryków Herberta w Niemczech, czyli do czasu pojawienia się na rynku wydawniczym jego przekładu Pana Cogito ${ }^{25}$. Przed ukazaniem się wskazanego tomu publikuje liryki polskiego autora w takich zbiorach jak Lektion der Stille (1959), Gedichte (1964) albo Inschrift $(1967)^{26}$. A w 1974 roku zostaje wydany nakładem wydawnictwa Nenes Lében w bylej NRD wspomniany wcześniej wybór przekładów wierszy I Ierberta Poesieallum 86, w którym dokonane przez nich thumaczenia publikują Karl Dedecius, Bernd Jentzsch, Wolfgang Jöhling, Rainer Kirsch i I Icinrich Olschowsky (ZI IP'a).

\section{Przekład jako „świadectwo odbioru” i „reprezentacja”}

Thumacz jest zarówno odbiorcą literackim, jak i nadawcą własnego komunikatu, poświadczającego estetyczny odbiór rzeczywistego dzieła sztuki. Występując w roli nadawcy, zakłada określonego odbiorcę, .wpisanego” w inny kontekst kulturowy, uksztaltowanego przez odmienną tradycję, mówiącego innym językiem niż adresat utworu oryginalnego.

23 Zob.: Im Viaterland der Mythen, wyd. K. Dedecius, tl. K. Dedecius. K. Stacmmler, W. Tiel, Frankfurt am Main 1973 (Ls); Z. Herbert, Der sordische Knoten. tl. H. Bereska, Berlin 20)1 (wyd. ilustrowane rysunkanui autora): idem, Der Tulpen bitterer Duff. th. K. Staemmler. Frankfurt am Main 1995; idem, Ein Barbar in eincm

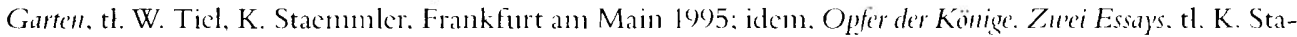
cmumler. Frankfurt am Main 1999 (wyd. I: 1996): idem. Stilleben mit Kandare. Skizzen und . Apokryphen. tl. K. Stacmmler. Frankfurt am Main 1994. Dedecius w drugim tomic dzicla swojego życia zannieszcza wiersze Herberta $z$ lat 1956-1974 (1)PR t. 2, Zïrich 1996. s. 131-156.

${ }^{2+}$ Zob. Z. I Ierbert, Beridet aus eimer belegerten Studt mol andere Gedidete. th. O. J. Tauschinski, Frankfurt an Main 1985; idem, Rovigo. Gediche, th. K. Stacmmler. Frankfurt am Main 1995. Po sumicrei Herberta (1998) ukazal siç nakładem wydawnictwa Sulırkamp Epilog burzy w tlumaczeniu I Ienryka Bereski (Z. Herbert. Geuriter Epilog. Gedichte, tl. H. Bereska, Frankfurt am Main 1998) oraz pojawił się tom przckladów liryki

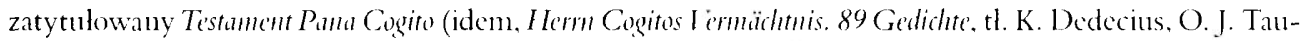
schinski, K. Stacmmler, Frankfurt an Main 200(); dalej cyt.: HCV).

s5 „Herr Cogito” Reinhardowi Lanerowi (Der Didhter und sein Didhter... op. cit., s. 20)4) przypomina Herrn Ke'uner Geschiditen Bertolda Brechta (zob. B. Brecht, Gesammelte It'erke, t. 2: Prosa. Frankfurt am Main 1967. s. 375-415). Podobnc skojarzenia ma Jekutsch, która pisze, iz w Pamu Coggito została przywolana tradycja Kartezjańska, a także wystapiły aluzje do zmanych postaci literackich: Don Kichota i Pana Kennera Brechta (UJZH, s. 176). Wskazane analogic wymagalyby dokladnej analizy, która nic jest w tej chwili tematem moich rozwaziá.

2t Zob. K. Dedecius, Lektion der Stille, München 1959, s. 38-4l (dalej cyt.: LdS): ZHG: K. 1)edecius, PoInische Poesie des zumzigsten Jahtumderts. München 196t, s. 131-136 (dalcj cyt.: PIV): Z. Herbert. Inschrift. wyd. i tl. K. Dedecius, Frankfurt an Main 1967 (późnicjsze wyd. 1973, 1979; dalcj cyt.: I)ln). 
Slowa występujące w literackim pierwowzorze są - akcentuje Dedecius - „surowym materialem" (OWB, s. 83). Zadaniem thunacza jest odnalezienie w języku, na który przekłada, takich jednostek leksykalnych, które oddają, i co więcej: eksponują sens literackiego pierwowzoru (Sim-Gerechtigkeif - OWB, s. 83), a zarazem „naśladują licencję poetycką" oryginału. Nie ma pewności - zwracał uwagę Schleiermacher — czy należy trzymać się autora i jemu podporządkować adresata, czy może lepiej skupić się na odbiorze czytelni$\mathrm{czym}^{27}$. Nic dziwnego, że każdego tłumacza dręczą wątpliwości, kiedy staje przed koniecznością szukania właściwych środków artystycznych w celu oddania sensów, wynikających z utworu oryginalnego. Autor przekładu uczestniczy przecież w spotkaniu dwóch kultur, co zobowiązuje go do szukania literackiego porozumienia z czytelnikiem, a zarazem do pamiętania o autorze oryginału ${ }^{28}$. Dokonane przez niego wybory są świadectwami odbiorı, wyrażającymi indywidualne decyzje tłumacza, które nie wynikają z odmienności dwóch systemów językowych, lecz są uwarınkowane jego kulturą literacką ${ }^{2 "}$. Na określenie metod przekladu, stosowanych przez thunaczy, posługuję się pojęciami zapożyczonymi ze starożytnej retoryki, które wykorzystał Jerzy Ziomek w rozważaniach nad styliza$c_{a} q^{30}:$ a diekcja, polegająca na wprowadzeniu dodatkowych wyrazów, niewystępujących w oryginale, detrakcja, czyli eliminowanie znanych z literackiego pierwowzoru słów, wyrażeń, zwrotów i zdaí, a nawet dluższych fragmentów tekstu, oraz i m m u t a c ja , przejawiająca się w zastępowaniu jednostek leksykahnych czy dhuzszych wypowiedzi przez słowa i zdania, które nie są ich językowymi ekwiwalentami. Należaloby jeszcze wymienić transmuta cję. Rozpoznajemy ją po zmianie kolejności słów i zdań, a niekiedy nawet obszernych sekwencji thumaczonego utworu.

W celu sprawdzenia, jak Dedecius i Jölıling interpretıja „liryki wojenne” Herberta, skupiam się na prozodii i leksyce, a także przeksztakceniach znaczeniowych oraz składni i frazeologii analizowanych przekładów. Rozumienie jest przecież — pisze Gadamer — „wyjaśnianiem" (Auslegen), dokonującym się poprzez język thumacza, nazwanego przez przywolanego filozofa „komentatorem”" (. Anskeger) ${ }^{31}$.

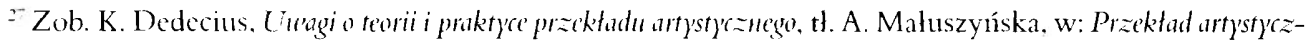
n). O sztuce thmmacienia ksiega druga, red. S. Pollak. Wroctaw 1975, s. 20.

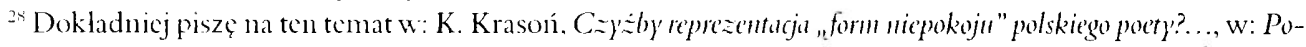
ezja polska i niemiecka u' przektudach u'spétczestych.... op. cit., s. 231. Wspominam o tym także w: Suriat po-

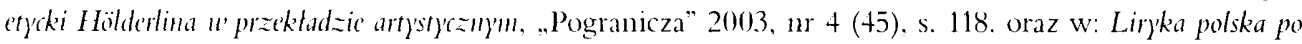

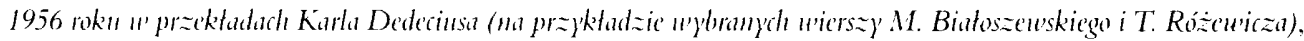
w: Dialog kultur u' Voucj Europie. Historia, liferatura, jezlk, red. K. Iwan, E. Komorowska, A. Rell. J. Zywczak. Szczecin 20013, s. 59-60).

2" Zob. M. (iłowiniski. Sirtadectu'a i style odllioru..., op. cit.. s. 121-123.

3" Zob. J. Zionnck, Parodia jako problem retorykii. w: idem. Ponrinouractura literatury'. Studia i szkice, Warszawa 1980. s. 371-372.

${ }^{31}$ H. G. Gadamer. I'ah hleit und Methode. Tübingen 1960). s. 366. 
Dedecius uważa, iz „sens kopii artystycznej dziela leży w jego artyz m i e" (moje podkr. K. K.) ${ }^{32}$. Autor przekładów literackich nie ogranicza się do reprodukcji określonego materiału, gdyż przez wydobywanie z obiektu artystycznego istniejących juz sensów i rekonstrukcję poetyki pierwowzoru tworzy dzieło sztuki literackiej, traktowane w niniejszym szkicu — zgodnie z propozycją Romana Ingardena — jako „przedmiot estetyczny” i ,intencjonalny”.3. Ocena przekładu wymaga również ustalenia jego statusu. Dzieło thumacza nie jest traktowane jako niezależne od dzieła poety. Znajdıje się wprawdzie poza oryginalem, ale wyrasta przecież z określonego pierwowzoru. Nie można również - sugerowalam - oczekiwać od przekladı, że będzie idealnym odbiciem tekstu pierwotnego. Wobec tego należy traktować go jako „reprezentację” oryginatu, bowiem ma on za zadanie - zanważa Krzysztof Mróz - „reprezentować” inne dzieło ${ }^{3+}$, to znaczy wyrażać wynikające z niego sensy, w wykreowanym przez thumacza, sztucznym świecie poetyckim, przy jednoczesnym zachowaniu klimatu oraz licencji poetyckiej przekładanego tekstu. Rzeczywistość przekładı jest sztuczua w tym sensie, że nie odzwierciedla oryginalnego świata poetyckiego, lecz go naśladuje. Staje się - powtórzıny za Marią Renatą Mayenową - znakiem ikonicznym fikcyjnej rzeczywistości literackiej, która jest znana z literackiego pierwowzoru ${ }^{35}$.

Język oryginału oraz przekladu traktıję za Wilhelmem Humboldtem jako „obraz” kultury danego narodu ${ }^{36}$. Zatem sprawdźmy, jakie obrazy poetyckie kreują wspommiani thımacze: Dedecius (RFN), który został uznany przez Lauera za "poetę poety " ${ }^{37}$, i Jöhling (NRD), co pozwala dostrzec różnice między interpretacją „wierszy wojennych” Herberta w Niemczech Zachodnich i Wschodnich ${ }^{38}$. Przeciez interpretacja - pisze I)decius -

${ }^{32}$ K. Dedecius. Netatmik thmincan, tl. J. Prokop. I. i E. Naganowscy. wst. J. Kwiatkowski. Warszawa 1988. s. 75 .

${ }^{33}$ Wedlug Ingardena, do dzieła sztuki nuoże należeć kilka przedmiotów estetycznych, przez które ono siç

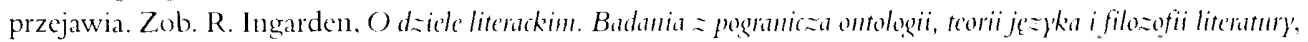
t1. M. Turowicz. Warszawa 1988; por. z: idem, Ceysto intencjonalny' przedmiot prostego aktn muiemania. w: ibidem. s. 179-212.

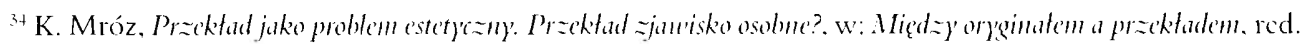
M. Filipowicz-Rudek. J. Konicczna. M. Stoch. Kraków 1977, s. 101.

${ }^{35}$ Przcklad, traktowany tutaj jako znak ikoniczny literackicgo picrwowzoru. jest w pewnym sensic stylizacja (zob. M. R. Mayenowa, op. cit.).

${ }^{36}$ Borsche następująco streszcza filozofiç języka i kultury H Hunboldta: ..Styl był dla niego zagadnieniem charakteru. Badanie charakteru - osób i narodów, krajów i cpok - zajnowalo go całkowicic” (.. Dér Stil war ihm die Frage des Charakers: Dic Erforschung des Charakters - ron Personten und Natione'n, ren Ländern und Zeite'n

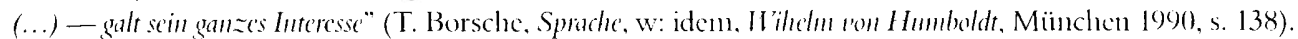

${ }^{37}$ Tak Reinhard Laucr - za Novalisem, którego rakże często przytaczal 1)edecius, mówiąc o dążeniach rzetelnego thumacza - zatytulowal mowę laudacyjną z okazji przyznania Dedeciusowi i I lerbertowi nagrody S. B. Lindego wspólpracujących ze sobą uniwersytetów w (ietyndze i Tormuiu (zob. wyżej przyp. 5).

${ }^{3 *}$ W NRD nicpokoito krytyków wszystho, co podwazalo - pisze Olschowsky — „monopol światopoglądowy marksistowskicj partii”. W związku z tym „postawy recenzenckic” i .,wzorce odbioru daja siç podciągną̧ pod pojęcic zdrady t wór z zoj" (H. Olschowsky, Idcolegiczac u'zorce odhioru, op. cit. - moje podkr. K. K.). 
często traktowana jako objaw rzekomej glupoty thumacza - choć może być kłopotliwa dla laika, jest jednak nieodzowna: ponieważ tłumaczyć znaczy przenikać istotę rzeczy, udostępniać ją zmystom, czyli interpretować ${ }^{39}$.

\section{„Wiersze wojenne” Herberta z tomu Struna śuiatła w przekładach Dedeciusa i Jöhlinga}

Pisałam, że zbiorek liryczny Struna śuratta (1956) zawiera - oprócz nawiązań do europejskiej tradycji kulturowej - także motywy polskie. Zbiorek, w którym - pisze Olschowsky - Herbert identytikuje się z „pokoleniem Kolumbów”: Baczyńskim, Rózewiczem i Borowskim ${ }^{+1}$. Przekładów wierszy autora Napisu, nawiązujących do wojny i okupacji, jest w Niemczech niewiele. Mimo że krytycy i tłumacze - należą do nich zwłaszcza: Lauer, Dedecius, Olschowsky, Krïger, Jekutsch — dostrzegają w lirykach poety wcześniej sugerowane nawiązania do polskiej historii, drudzy z wymienionych starają się w swych przekladach zwrócić uwage czytelnika na wspomniany un iwe rsalizm twórczości autora Rovigo — tak na przykład Dedecius przelożyl tylko kilka wierszy o tematyce wojennej z tomów Struna śu'iatta (1956) i Hermes, pies i guriazda $(1957)^{41}$, a przetlumaczony przez niego wiersz Herberta Pį̣ciu (H Ipig, s. 76-77) - Die Füllf zostal także opublikowany w antologii Staemmlera Polska z pienuszéj ręki. Historia i teraźniejszość u' sprau'ozdaniach i dokumentach (1975), którą inicjuje następująca wypowiedź jej redaktora:

Poświęcona memu ojcu, zabitemu 9 września 1939 roku w pobliżu Łowicza przez Polaka, i ojcu mego polskiego przyjaciela, zamordowanemu 24 czerwca 1942 przez Niemca w obozie koncentracyjnym w Dachau, ażeby żaden Polak i żaden Niemiec już więcej nie ginęli z nienawiści między dwoma sąsiadującymi narodamit2.

Warto dodać, że przejmujący liryk I Herberta został także przytoczony w całości pod komentarzem redakcyjnym do wypowiedzi Heinricha I Iimmlera Polen als Sklaven'olk („Polacy jako naród niewolniczy”), co jest jeszcze jednym argumentem na rzecz wcześniej sugerowanego po-

${ }^{39}$ Cyt. za: J. Hummel, Najnou'sza Hagroda dla Zbignie't'a Herberta, „Poczja"1973, nr 12, s. 35.

+" Poeta jawi się - zdanicm badacza - zarówno w swych debiutanckich wierszach. jak i późniejszych, jako „straznik grobów” (OFLM. s. 170).

"Do ..wierszy wojennych" Herberta thumaczonych na język niemiecki należą Poíegnnanie u'rzéśnia (Sś, s. 8) - Hoschied rom Semprember (ZHPa, s. 8); Cinentar unarszan'ski (Sś, s. 42) - Warschaner Friedhof (ZHG, s. 42): Durie krople (Sś. s. 5) - Zu'ci Tropfen: Pį̧ciu - Dic Fïnf (I Ipige s. 76-77) - (†) ZH HG, s. 61; (††) ZHPa, s. 18; (†††) DIn, 87: (††††) HCV, s. +(). Znaki (†).(††) itd. wskazuja na kolejne wersje przckladu i zmiany w nich dokonywanc.

+2 K. Staemmler. Polen ans erster Hand. Geschichte und Gegenu'art in Berichten und Dok'nmenten, Würzburg 1975 , s. 1. 
strzegania w Niemczech I Ierberta — tak jak Różewicza — jako poety „pokolenia Kolumbów”, nawiązıjącego w tworzonej przez niego poezji do tragicznych wydarzeń z lat 1939-1945:

Niezwykle brutalna polityka nazistów była nastawiona na wyniszczenic wiodących warstw spolecznych (inteligencji i duchowieństwa), a także na bezwzględne wykorzystanie sily roboczej pozostalych. Wszyscy polscy Żydzi byli skazani ua śmierć (...). W wierszu wielkiego polskiego liryka, Zbigniewa I Ierberta, znajdziemy odzwierciedlenie tej sytuacjit ${ }^{+3}$.

Spośród utworów nawiązujących do lat 1939-1945 najwiçksze zainteresowanie niemieckiej publiczności literackiej — zaznaczalam - wzbudził liryk I Ierberta Nike która się waha (Sś, s. 73-74), znany w Niemczech dzięki przekladowi Dedeciusa. Gert Westphal stwierdzil, że właśnie ten wiersz wywarł na nim szczególne wrażenie. Zachwycil również Dedeciusa, który uznal go za najpiçkniejszy, a zarazem najcichszy i najsubtelniejszy liryk antywojenny ze wszystkich, jakie kiedykolwiek czytał (D)PR, s. 591). W innej pracy: Übcrall ist Polen [Wszzqdzic (jest) Polska] powoluje się na sąd Gïntera Wirtha z Sïdd'utscher Rundfunk, który uważa wiersz I Ierberta za - cytuję za Dedeciusem - .jeden z najpiękniejszych poematów, w którym mówi się o całym pokoleniu wojny i okupacji”tt (I)PR, s. 592). Nic dziwnego, ze ten popularny za naszą zachodnią granicą utwór poetycki uczynił Olschowsky przedmiotem dokładnej analizy - ale do tego jeszcze powrócę.

Nieznaczne różnice, na które zamierzam zwrócić uwagę, można dostrzec między pierwszą wersją przekladu z 1959 [(†) LdS, s. 39-40] a drugą z 1964 roku [(††) ZI IG, s. 22-23] oraz pozostalymi. Przytaczan czwartą wersję, pochodzącą z 1974 roku, w niewielkim stopniu różniącą się od drugiej, znanej z wydanej o dziesięć lat wcześniej antologii Gédichte ${ }^{+5}$ :

\title{
Nike która się waha ${ }^{\text {th }}$
}

\author{
Najpiękniejsza jest Nike w momencie \\ kiedy się waha \\ prawa ręka piękna jak rozkaz \\ opiera się o powictrze \\ ale skrzydla drzą
}

\footnotetext{
I. Ibide'm, s. 183-184.

${ }^{+}$K. Dedecius, Die polnische Poesie in De'utsthlund, op. cit.. s. 87.

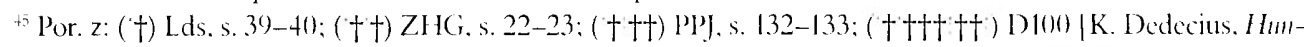

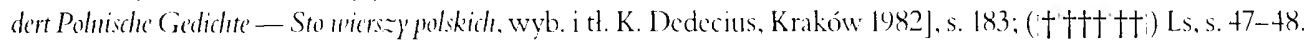

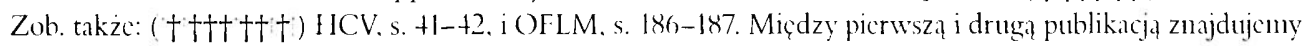
niewielkic różnice. ale tylko na poziomic mikrotekstu. Dedecius w pełni akceptuje czwarta propozycje przekladu

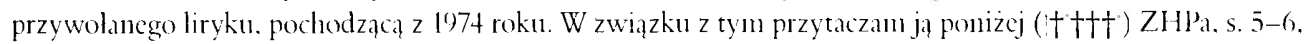
moje podkr. K. K.). 1) kolcjnych edycji przywotancgo ntworu thumacz nic wprowadza zadnych zmian.

th Sś, s. 74 - moje podkr. K. K.
} 
widzi bowiem

samotnego mlodzieńca

idzie długą koleiną

wojennego wozu

szarą droga w szarym krajobrazic

skal i rzadkich krzewów jałowca

Ow młodzieniec niedługo zginie

whaśnie szala z jego losem

gwałtownie opada

ku ziemi

Nike ma ogromną ochotę

podejść

pocalować go w czoło

ale boi się

że on który nie zaznal

shodyczy pieszczot

pozilawszy jaz

mógłby uciekać jak inni

w czasie tej bitwy

więc Nike waha się

i w końcu postanawia

pozostać w pozycji

której jej nauczyli rzeźbiarze

wstydząc się bardzo tej chwili wzruszenia

rozumie dobrze

że jutro o świcie

muszą znaleźć tego chłopca

$z$ otwartą piersią

zamkniętymi oczyma

i cierpkim obolem ojczyzny

pod drętwym językiem

Nike wenn sie zögert

Alm schönsten ist Nike

"l'e'un sie zögert

die reche hand an die huft gelelunt

herrlich wiecin befehl

aber die fliigel zittern 


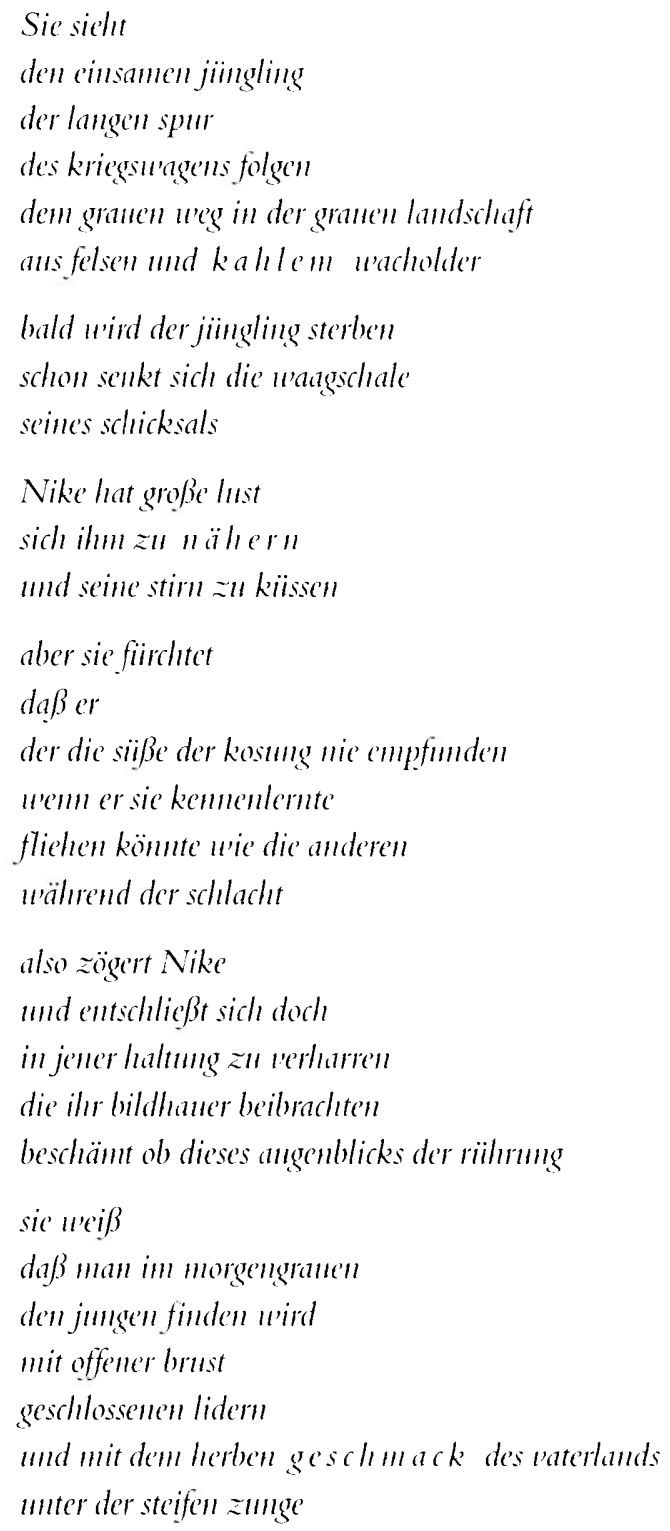

W cytowanym przekładzie Dedecius naśladıje intonację oryginału przez zachowanie takiego samego podziału stroficznego oraz zblizonej do wicrsza I Ierberta liczby zglosek w poszczególnych wersach. Zauważalna tutaj tendencja do skrótu poetyckiego znajdıje wyraz na przykład w zastosowanej przez niego w pierwszym wersic metodzic detrakcji: zdanie "Najpiękniejsza jest Nike w mo me n c ie / kiedy się waha” (Sś, s. 73 - moje podkr. K.K.) dałoby się bez trudu przelożyć choćby przez zastapienie występującego w oryginale zdania czasowego (niem. Temporalsatz) zdaniem przydawkowym (Attributsatz lub Relatiesatz): An schönsten ist Nike 
im Moment (im Augenblick) / in de'm sie zägert. Thumacz jednak decyduje się na zdanie czasowe (Temporalsatz), w którym świadomie opuszcza występujący w oryginale okolicznik czasu, w celu oddania spokojnej intonacji liryku I Ierberta. Takie postępowanie wynika także z konieczności językowej ${ }^{+7}$ : „4 Am schönsten ist Nike / wenn sie zögert”. Stosuje również metodę detrakcji w wersie inicjującym druga strofę. Opuszcza pojawiające się w oryginale słowo „bowien”, które można byłoby zastąpić spójnikiem ueil lub da: we il sic / den cinsamen jïngling sieht. Wówczas zostalaby zakłócona cicha i delikatna intonacja wiersza. Wiersza, w którym — cytıję I)edeciusa - .do niczego się nie agituje, nie polemizuje się z kimkolwiek, niczego się nie zaprzysięga” (op. cit., s. 591). Tłumacz daje temu artystyczny wyraz przez unikanie słów wywołujących dynamikę ruchu i emocji, na przyklad eliminuje występujący w oryginale okolicznik sposobu: „gwaltownie” (niem. genaltig). Nic nie stoi przecież na przeszkodzie doslownego przełożenia dystychu zamykającego trzecią strofkę jako: schon senkt sich ge w'altig die u'angschale / seines schicksals. W wyniku skorzystania przez Dedeciusa z metody detrakcji wypowiedź liryczna staje się krótsza, a jej intonacja spokojnicjsza, bardziej wyciszona.

Dedecius przez unikanie tłumaczenia „słowo w słowo” (Wort fiir Wort), przejawiające się w częstym stosowaniu wspomnianej metody, kreuje — niczym Herbert - przepiękny, chociaż ponury obraz poetycki, na którym nie pojawia na tle szarego krajobrazu - cytuję thumacza — „promieniejąca bogini zwycięstwa, le c z aniol zwątpienia, wspólczucia i wstydu” (DPR, s. 592 - moje podkr. K. K.) ${ }^{+3}$. Przeciez Nike - pisze Lam - jest świadoma nieuchronności losu, na którego bieg nie ma wpływu. Badacz podkreśla — tak jak Dedecius - że role pelnione przez bohaterów zostają w wierszu odwrócone, wbrew czytelniczym oczekiwaniom. A triumfalna poza, nadana greckiej bogini przez rzeźbiarzy, oznacza pozor ne zwycięstwo +":

To nie chłopiec — podkreśla Lam — waha się między wyborem szczęścia osobistego a obowiązkiem wobec ojczyzny — jak to często przedstawia się w literaturze - lecz bogini okazuje w jedncj chwili - i to w sposób prawie niezauważalny - l udzk ą s labość. Jej statyczność jawi się nie jako konsekwencja

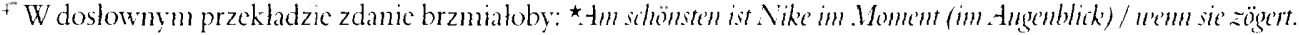
Bylaby to jednak konstrukcja skladniowa nicpoprawna gramatycznic, nic do zaakceptowania przez adresata przekladu. Dedecius. zwłaszcza w thumaczeniach polskicj poczji lingwistycznej. stawia na dosłowność. na przykład wystçpujace w liryku Karpowicza Czarne i bute (zob. T. Karpowicz. Kumicmua muzyka. Warszawa 1958. s. 52) wyrażenic cammi ibiali ludzic thumaczy dosłownie: schmarze und ureiße menschen (PPJ. s. 121). W ten sposób może wywobać u odbiorcy skojarzenia z ludzkiq rasą. do czego liryk Karpowicza nie prowokuje. Piszę na ten temat

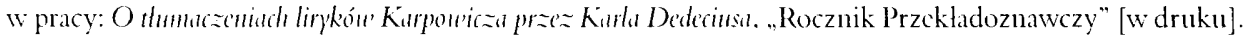

${ }^{+\lambda}$ Herbert nie ukazal w wierszu martwego posaggu. lecz pelną wątpliwości kobietę, która niepokoi siç o los żohnicrza. Zatem obdarzyl ją rysami hudzkinin. W wiçkszości utworów - zauważa Dedecius - pocta ukazuje postacie mityczne w sytuacjach codziennych, postacie. które pelne są ludzkich slabości (DPR, s. 582). Zob. także wiersz Herberta Siódmy amiol: ..Szemkel / jest czarny i nerwowy / był wiclokrotnic karany / za przemyt grzeszników" (Hpig, s. 61).

*" Por. z interpretacją: A. Biskupski, „. Vike króra się u'alu" i „Ognista Nike” allbe ofatalizmie. „Miscellanea Lódzkič, 1993. z. 1.
} 
skostniałcj idei, ale jako wyraz dobrowolnie przejętej roli - wszak znaleźli się rzeźbiarze. Nadali jej pozę, w której wyczuwa się „podmuch triumfü "

Dedecius - latwo się donyślić — opisuje pomnik warszawskiej Nike, będącej bohaterką liryku I Ierberta. W artystycznie wartościowy sposób zwraca uwagę na występowanie w utworze dwóch konwencji, określonych przez Olschowsky’ego jako ,artystyczna” i „patriotyczna”, do których poeta ma nastawienie polemiczne:

Reguły sztuki zostają umocnione przez dążenie do wyłamania się z nich po to, aby scharakteryzować aktualny konflikt. Patriotyczna konwencja, która zostaje tutaj podana w wątpliwość, to ukazany w utworze ideał natychmiastowej gotowości do walki (OFLM, s. 188; por. z DDH, s. 43).

We wszystkich wersjach przektadu, zwlaszcza w drugiej [ ( † † ZGI I - 1964], Dedecius próbuje oddać ambiwalencję uczuciową bohaterki przez zastosowanie odpowiednich środków stylistycznych, które nie zawsze występują w oryginale, na przykład zastępuje polski czasownik „zginąć” w zwrocie „Ów młodzieniec niedlugo zginie” (Sś, s. 73) jednostką leksykalną „sterben” (zam. fallen), co nie deformuje sensu oryginału. Ponadto w drugiej wersji tłumaczenia, pomieszczoncj w wyborze przekładów liryków Herberta z 1964 roku, wskazana immutacja wprowadza do przekładı pewien niepokój: w wersie inicjującym trze-

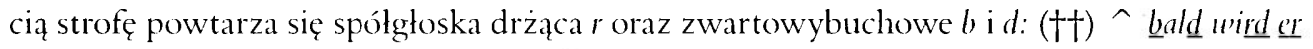
sterben / der jüngling [(†) ZI IG, s. 22] ${ }^{51}$. W związku z tym zmienia się tonacja monologu lirycznego ze sprawozdawczej na moralizująco-retoryczną, której tłunacz nie zachowuje w większości późniejszych wersji tłumaczenia przywołanej sekwencji wiersza ${ }^{52}$. Nie jest wykluczone, że Dedecius, który pisze w posłowiu do przywolanego zbiorku lirycznego, iż I Ierberta z Miłoszem lączy „moralizująca retoryka” $\left[(+\dagger) Z\right.$ IG i, s. 106] ${ }^{53}$, daje temu ar-

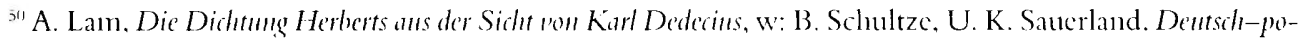

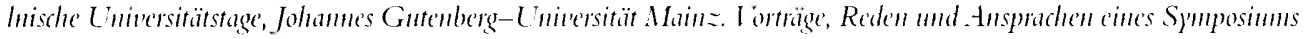
im Norember 1988, Mainz 1989, s. 43 (dalej cyt.: DD)11).

51 ^ — zuak wskazujący na skorzystanic przez jedncgo lub kilku tlumaczy z różnych nożliwości przckladu tego sancego fragmentu utworu.

"Począwszy od 1964 roku Dedecius nic powraca już do pierwszej propozycji niemal dosłownego thumaczenia [LdS, s. 39-40]: dieser jüngling uird hald sterten (moje podkr. K. K.) Po 1974 roku siçga nickiedy do czwartej propozycji tlumaczenia liryku I Ierberta z 1974 roku: ^ bald wird der jïngling sterlon [(††††)

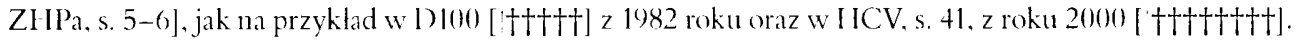
${ }_{53}^{3}$ Sicmiaszko pisze. ze na pytanic: ..czym jest cnota? (...) Milosz odpowiada w duchu I Ieraklita. wszystko względne. inne micjsce, inna odpowiedzialnośc, inna hicrarchia wartości, czlowick pogrążony jest w niepewuości i musi za każdym razenn tworzyć swój porządék egzystencjalny i moralny na nowo, dostosow ując go do zmieniającego siç nieustannic świata. Herbert przeciwstawia tak relatywnic pojmowancj moralności pewność stalych norm i zasad. Nie nua i nie może być względności w świecic pogrążającym się w chaosie i nihilizmie" (P. Sicniaszko, Zmiennośc i trmanie, O eseistrac Zligmiena Herberta. Bydgoszcz 1996. s. 162).
} 
tystyczny wyraz w przytoczonym wyżej fragnencie drugiej wersji przekładu. We wszystkich propozycjach thumaczenia, a zwhaszcza w cytowanej tutaj w calości, dąży - sugerowano - do maksymalnej kondensacji stów i myśli. W związku z tym rezygnuje z metody adiekcji, co czyni rzadko w przekładach wierszy Herberta, i w jeszcze większym stopniu - Tymoteusza Karpowicza czy Mirona Białoszewskiego. Zastępuje polskie jednostki leksykalne odpowiednikami niemieckimi, które pozwalają zachować zwięzłość wypowiedzi poetyckiej, jak inicjujący ostatnią strofę wers: „ro z u m i e dobrze” (Sś, s. 74 - moje podkr. K.K.) — dosh. sie versteht gut - zastępuje zwrotem "sic weiß" (ona wie) [( ††††) ZI IPa, s. 5], a w miejsce kończącego drugą zwrotkę wyrażenia „skał i r z a d k i ch krzewów jałowca” (Sś, s. 73 - moje podkr. K. K.) - dosł. Aus Felsen und sel te ne n (lub: s pälirlichen Sträuchern

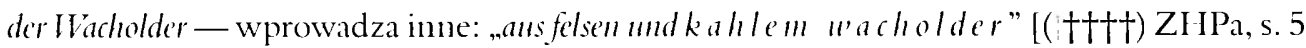
— moje podkr. K. K.]. W wyniku zastosowania w przekładzie ostatniego z przytoczonych wersów takich metod, jak immutacja i detrakcja: „kahler wadiolder” („ysy, goły, ogołocony / calkowicie pozbawiony igliwia jałowiec" ${ }^{5+}$ ) — cytowana tutaj krótka fraza brzmi bardzo poetycko, a zarazem zostaje w niej wyeksponowane surowe, ponure, pozbawione roślinności, nieprzyjazne to krajobrazu otaczającego bohaterów, na które zwraca uwagę Dedecius w dokonanej przez niego interpretacji utworu: ,mlodzieniec jest szary, droga jest szara, krajobraz jest szary. Poeta nie potrzebuje więcej barw dla swego obrazu ludzkiej samotności" (DPR, s. 592) ${ }^{55}$. Nic dziwnego, ze Olschowsky dostrzega w przywolanym liryku ślady $\mathrm{k}$ at a strofiz mu, obecnego w poezji Miłosza (OFLM, s. 189).

W dystychu zamykającym utwór Dedecius rezygnuje z dosłownego thumaczenia zdania, zastępując słowo „obol” (niem: Obolos lub Obolıs) jednostką leksykalną „Geschmack” (smak), przez co staje się bliższy przyzwyczajeniom językowym odbiorcy. Unika przez to — pisze Lam — „nadmiaru antycznego sztafaż” (DI)I I, s. 45). „Obolowi” nadał jednak Herbert - zdaniem badacza — głçboki sens:

\footnotetext{
${ }^{3+}$ Z oryginału wynika, że wymicniony krzew rośnic tylko gdzieniegdzie, czasem można go spotkać (,,rzadkic krzewy jałowca" - Sś. s. 73). Nic jest wykluczone, ze Dedecius posłużył się immutacją nieświadomie, bowicm jalowice zawsze jest ziclony, nigdy nic traci igicl. Można jednak przypuszczać. że clicial ukazać spalony krzew jako konsekwencjৎ̣ dzialań wojemnych. Zatem z przckladı wynika, że na skutek kataklizmu nawet jałowiec stracil kolor, stał się częścią opustoszalego, szarego krajobrazu, przez co wykreowany przez Dedeciusa, wstrząsający wizerunck poetycki brutalncj rzeczywistości wojenncj. przypomina katastroficzno-apokaliptycznc wizjc Milosza. Warto dodać. że Dedecius i Olschowsky zwracają uwagę na poetyckic pokrewieństwa między Herbertem a Miloszem (ZI IG, s. 106; por. z: OFLM, s. 189).

"Można tutaj także zauważyć związek z kolorystyką Gerarda Terborcha, która dla Herberta - zauważa Siemiaszko (op. cit.. s. 58) - byla glównym przedmiotem uwagi. Pocta daje wyraz swej fascynacji przygaszoną barwą jego plócien. godne podziwu u Terborcha jest „unikanic gwaltownych zestawicń kolorystycznych, tonacja obrazu chlodna i przcjizysta, gradacja szarości az do zanykająccj obraz majestatycznej czerni" (Z. Herbert, Martwa natura z wędzidlem, Wrocław 1993, s. 86). Wspomniany badacz zauważa równicż (ibidem), iz Herberta zachwycają przythumionc szarości Corota: o wspomnianym artyście Herbert pisze w szkicu o malarzach francuskich następująco: ,jakże operuje on szarością, która ma dźwiçk najbardziej jaskrawych kolorów” (Z. I Herbert. Od Dalida do Cezanme'a, „Twórczóśc” 1956, nur 8, s. 4).
} 
Obol, symbol ziemskiego bogactwa, które zostaje przeniesione do tantego świata, redukuje idę poświęcenia dla Ojczyzny do tej nędznej, pośmicrtnej „wyprawy” (I)DI I, s. 45 - moje podkr. K. K.).

W przekładzie Jöhlinga zauważa się skłomność do zastępowania polskich słów, zwrotów i wyrażeń niemieckimi jednostkami leksykalnymi, które oddalają się znaczeniem od oryginalnych, a nawet pozbawione są bezpośredniego związku semantycznego z nimi, przez co thumacz kreuje wstrząsający obraz rzeczywistości wojennej:

\section{Pożegnanie września}

Dnic były a ma rantowe

błyszczące jak lanca ułańska

śpiewano w megafonach

anachroniczną piosenkę

o Polakach i bagnetach

tenor ciąl jak szpicruta

i po każdej zwrotce

ogłaszano listę żywych torped

które notabene

przez sześć lat wojny

szmuglowaty stoninę

żałosne niewypały

wódz podnosil brwi

jak buławę

skandowat: ani guzika

śmiały się guziki:

nie damy nie damy chlopców

plasko przyszytych dowrzosowisk

\section{Abschied vom September}

He idek rautrot uraren die tage

wie nlane'ulanzen

in den lautsprechern sang wer

5o Sś. s. 8- moje podkr. K. K.

${ }^{57}$ W. Jöhling: ZHPa, s. 26-27-moje podkr. K. K. 


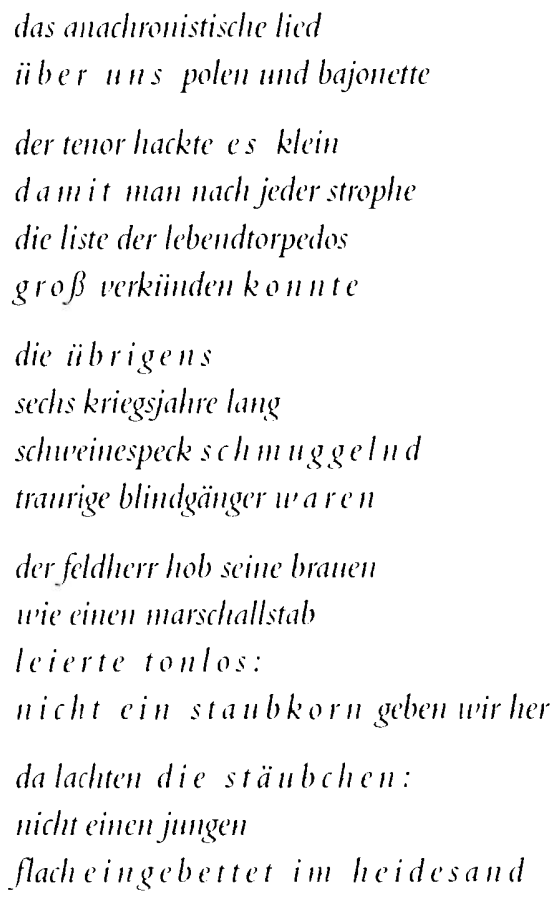

Wers inicjujący liryk I Ierberta: „dnie były amarantowe” można byłoby przełożyć doslownie: Die Tage uaren amarantrot lub: amarant(en), amarantfarbig czy dunkelrot. Stowo ,amarantowe" - slusznie twierdzi Jekutsch - przywołuje w wierszu kontekst historyczny, ponieważ oznaczało barwę państwową Księstwa Warszawskiego, założonego w 1807 roku. Księstwa, które było formalnie niepodległe, ale faktycznie podporządkowane Napoleonowi (UJZH, s. 118). Jöhling zastępuje epitet „amarantowe” innym określeniem: „Heidekrautrot” (czerwień wrzosu), które umieszcza na początku zdania. Jednostka leksykalna Heidekraut (wrzos) pojawia się nieprzypadkowo w części inicjalnej wiersza, ponieważ wiąże pierwszą z ostatnią strofą przektadu: .nicht einch jungen / flach eingebet te't im heidesand" (moje podkr. K. K. ${ }^{58}$. Z przekładu wynika - tak jak z utworu I Ierberta - ze wrzosowiska sa pełne krwi (amarantowe) niczym lanca ulańska, będąca atrybutem walczącej kawalerii ${ }^{59}$.

\footnotetext{
${ }^{3 \times}$ W picrwszym wersie występuje „czerwicń wrzosu” (Heidekrautrot), a w ostatnim „piasck na wrzosowisku” (Heidesund). W ten sposób Jöllling nadaje przckladowi kompozycję picrścicniową (Ringstruktur), którcj nic znajdujemy w oryginale. na co zwraca twag̨ Jckutsch (UJZH, s. 189). Występujące w zakończeniu wicrsza zdanic możua byłoby przclożyć: ...ni jednego mlodzicíca / plasko leżącego [dosl.: ulożonego] w piasku na wrzosowisku”. Autor przekładu kreujc ponury obraz żołnicrzy poleglych w walce, „plasko przyszytych do wrzosowiske" (Śs. s. 9-11nojc podkr. K. K.). Nic n a śla duje jednak w przekladzic wystçpującj w oryginak aliteracji oraz instrumentacji gloskowej.

${ }^{34}$ Thumacz móglby takze zastąpić występujące w oryginale slowo „amarantowe“ takimi przymiotnikami jak blutrot czy purpurfarbig (purpum, purpurrot).
} 
Jöhling opuszcza jednak slowo „błyszczące” (niem. blitzend), przez co zostaje osłabione drugie z podanych tutaj znaczeń symbolicznych barwy amarantowej. Poeta nawiązal przeciez do rodzimych tradycji patriotycznych po to, aby zdemitologizować romantyczny mit Polaka walczącego za wszelką cenę o wolność. Potencjalni bohaterzy narodowi, którzy gotowi byli zginąć za Ojczyznę, przedstawieni są w liryku I Ierberta jako zwyczajni handlarze słoniną. Wynika z tego, że poeta demaskuje zdemitologizowane wyobrażenie wojny przez — cytıje Barańczaka - „konkretne, empiryczne doświadczenie" "(r) Jölıling decydıje się w przekładzie przytoczonego wersu na metodę immutacji i transmutacji w celu przyblizenia odbiorcom sensu liryku Herberta. W przekładzie drugiej strotki, w której występuje aluzja do znanej polskiej pieśni patriotycznej „Warszawianka”, thumacz posługııje się adiekcją. Wprowadza do przekładu - powiedzmy za Spasowską - element protetycznyy ${ }^{61}$ : „ïber mins" (o nas) ${ }^{62}$. Czyni tak w celı podkreślenia, iz w wierszu I Ierberta istotna jest Rilkeańska idea w spólodc z u wa n i a ${ }^{6.3}$ : podmiot liryczny identyfikuje się z pokoleniem, które stato się of iara procesu masowej zagłady ${ }^{6+}$. Thumacz stosuje takze metodę immutacji i adiekcji w przekładzie trzeciej strofy wiersza I Ierberta, na przyklad dokonuje zmiany na poziomie składniowym, polegającej na zastąpieniu zdania wspótrzędnie złożonego zdaniem podrzędnie zlożonym okolicznikowym celu (Finalsatz). Zatem przez rezygnację z imitowania oryginalnej sktadni proponuje wlasną interpretację literackiego pierwowzoru. Wskazuje na związki przyczynowe między zdaniami pojedynczymi, czego nie znajdujemy w liryku Herberta, w którym zauważa się przewage parataksy nad hipotaksą, a takze asyndetonów nad polisyndetonami (UJZII, s. 189). Przedstawia bardziej szczególowy niż w oryginale obraz rzeczywistości wojennej, jakby widziany oczami Polaka będącego świadkiem minionych

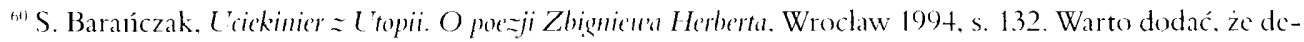
mitologizacja zdaniem Bultmanna i Blanka sluży „egzystencjalnej” interpretacji wydarzeń z perspektyw'y

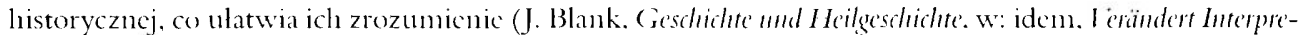
tation den Glauben?. Freiburg-Bascl-Wien 1972. s. 11).

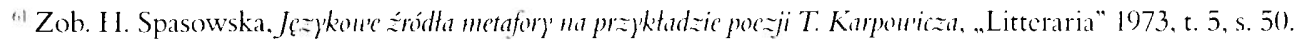

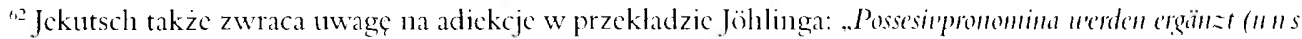

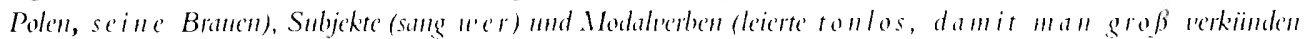
komme)" (UJZII, s. 189)

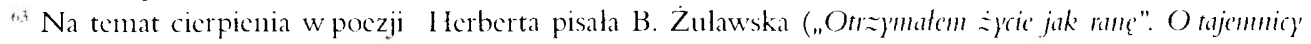
zta " pocji Zbignie'u't Herberta, .Prace Polonistycznc” 199(), Seria 46, s. 5-20). Natomiast rozważanom o wspólczuciu i współodezuwaniu w lirykach poety poświçcil sporo miejsca J. Poradecki (Atrytmetyka

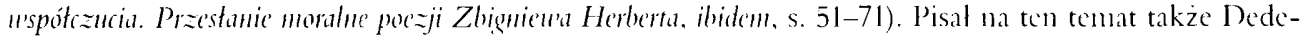
cius (Philosophic der Poesic, Poesie der Philosophice, w: Ost-llest Basar, wst. M. Cir. v. 1) Bhhnhoff. Zürich 1996. s. 191-207). Jerzy Kwiatkowski nazwal Herberta ..pocta wspolczucia”: ..Skrzywdzeni - to specjalnic uprzywilcjowani podopieczni jego wierszy” (J. Kwiatkowski, Imiona prostory', w: Posman'anie Herberta, wyb. i wst. A. Franaszek, Kraków 1998, s. 43).

"H Katarzyna Herbert (loc. cit.) wypowiada siç̨ nastçpująco: "Wciąż żył z poczuciem winy. Najpierw dlatego, ze inni zginçli - Gajcy. Baczyniski - a jemu nic się nie stato. Znat ich wiersze na pannięć (...). Wreszcic po stanic wojennym, dlatego że «był zbyt stary, żby nosić broń i walczyć. jak inni». Tak 1lapisal w Raporic z oblezoneso miasta". 
zdarzeń, przez posłızenie się - w przeciwieństwie do autora oryginalu - konstrukcja imiestowową (schureinespeck sch $m$ mggelnd - ZHPa, s. 27) oraz zdaniem przydawkowym (Attributsatz lub Relati'satz): Le'bentorpedeos (...) die ïbrigens (...) traurige blindgänger w'a ren (ZHPa, s. 27), a także przez rezygnację z występującej w literackim pierwowzorze elipsy ${ }^{65}$. W dwóch strofach kończących przekład liryku Herberta kreuje obraz poetycki, który różni się od lirycznej wizji polskiego autora. Z przekladı wynika, że „tenor ciął (sc. piosenkę — K. K.) jak szpicrutą, a że by (damit) po każdej zwrotce mogła zostać ogłoszona „lis ta ży wych torped" (ZHPal, s. 27), czego możemy domyślać się z utworu oryginalnego. Po zaśpiewaniu k rót k i e go fragmentu patriotycznej pieśni następowała przerwa („der tenor hackte es klein - moje podkr. K. K. ${ }^{60}$, co zostało również powiedziane w liryku Herberta, ale w inny sposób niż w przekładzie. Tłumacz opuszcza występujące w oryginale stowo „szpicruta” (niem. Reitpeitsche lub Reitgerte), która służy — wiadomo - do poganiania konia, co może nasuwać skojarzenie z odsylającym do polskich tradycji patriotycznych westernowym ujęciem wojny, w którym głównymi bohaterami byli ułani, o ile za istotę ułaństwa uznany — pisze Maria Janion — „lotne spojenie człowieka i konia ${ }^{67}$. Z oryginału wynika — zauważa Barańczak - że:

zgodnie z powszechnie obowiązującym mitem. piosenka zagrzewająca do walki wyraża wolę narodu; tymczasem doświadczenie uczy, że piosenka taka nie może być niczym więcej niż szpicrutą, instrumentem zarazem anachronicznym, „pańskim” i brutalnym, którym naród jak oporny wierzchowiec pobudzany jest do wysiłkuto

Zarówno w oryginale, jak i w przekładzie zostaje ukazana brutalność rzeczywistości wojennej, w której wojsko, mające za zadanie bronić donioslych wartości, staje się tylko — zauważa Barańczak - ,zabawką w rękach dyktatora" ${ }^{(6)}$, co także eksponuje Jöhling przez przytoczone wyzej krótkie stwierdzenie (ZI IPa, s. 27) ${ }^{7()}$. Wyzyskuje także dwuznaczność wyrazu hacken, które oznacza zarówno , siekać, rąbać”, jak i w przenośnym sensie: „wyrecy-

\footnotetext{
"W oryginale: ,żywe torpedy (...) żalosnc niewypały” (SŚ, s. 8). u Jöhlinga: „żywe torpedy. k tóre (..) by yy żatosnymi niewypahami" - . lebentorpedes die (...) tranrige blindsänger u'aren" (ZHPa, s. 27 - moje podkr. K.K.).

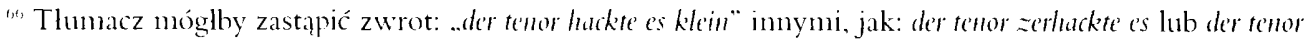
zerstïckelte e's. Nic zmicnilaby siç przez to moc illokucyjna wypowiedzi podmiotu lirycznego.

"M. Janion, Irojna i forma, w: Literutura uober mejny i okupacji, red. M. Glowiński, J. Slawiniski. Wroctaw 1976. s. 195.

in S. Barańczak. L'ickinier $=$ L'topii.... op. cit.

"3) Ibidem.

31 Wskazana immutacja nie jest podyktowana koniccznością językową. Fragment utworu: „tenor ciąl jak szpicrutą" mużna byłoby przctożyć nicmal doslownic: der temor schlung és uice cine Reitpeitsche. W ten sposób zostalby wycksponowana w przckladzic demitologizacja „westernowego mitu wojennego”, która ma micjsce w oryginale. Nasuwa siç tutaj powierzchowne skojarzenie z utworem Franza Kafki Auf der Galerie, w którym kobicta, która zarządzała cyrkicm, podawala takt szpicrutą.
} 
tować $\cos ^{71}$. Powiązane jest znaczeniowo ze zwrotem tonlos leiem (powtarzać coś do znudzenia) $)^{72}$. Przywolany zwrot, dla którego istnieje w języku niemieckin ekwiwalent słowny: skandieren (ZHPa, s. 27) zastępuje - wiadomo - znane z oryginalu stowo „skandować”. Odnosi się nie tylko do jednostajnego śpiewania pieśni patriotycznej, lecz także podkreśla przedmiotowe traktowanie żołnierzy wysyłanych na wojnę przez wodza sił zbrojnych. Żohnierzy, trochę przypominających bohaterów, którzy są znani z ekspresjonistycznych ıjęć wojny, w których utożsamiana byla z rzeźnią ${ }^{73}$. W ten sposób Jöhling ukazuje - cytuję Jekutsch - „początkową reakcję Polaków na niemiecki atak” (UJZI I, s. 186). W celu podkreślenia patetycznego tonu, towarzyszącego obwieszczaniu „listy żywych torped”, thumacz wlącza w kontekst wypowiedzi podmiotu lirycznego słowo gro $\beta$ (tutaj: dumnie, z dumą) $)^{74}$, przez co eksponuje emanującą z utworu I lerberta ironię, która staje się jeszcze bardziej wyczuwalna w następnej strofie przekładu ${ }^{75}$. Przez posłuzenie się metoda immutacji i adiekcji demitologizuje - niczym I Ierbert (!) - romantyczny mit straceníca, zatem „rycerza” walczącego o wolność narodı, który gotów byl z wlasnej woli złożyć swe życie na ołtarzı Ojczyzny ${ }^{76}$. Obnażający tikcję I Ierbert ukazuje zakłamany - cytuję Jekutsch — " "hurra-patriotyzm» w pierwszych dniach po wybuchu wojny i (...) wspomnienie polskiego ruchu oporu" (UJZH I, s. 188) 77 . W utworze I Ierberta zaatakowani Polacy nie chcą przecież dać się „zamknąé” we wspomnianym micie, a także „wpisać się" w rolę bohaterów, zafascynowanych wojną, utożsamianą z „kolorowym pasmem przygód ${ }^{7 n}$. W koń-

\footnotetext{
${ }^{7}$ Przykladowo zwrot: Sätze hackén oznacza ..wyrąbać" coś. wyrecytować zdania.

'? W kontckścic wypowiedzi poetyckicj zwrot tonlos leiern oznacza .zamęczyć kogoś monotonną wypowicdzią, nicustannym powtarzanicm - niczym katarynka — tych samych stów".

${ }^{73}$ Zob. M. Janion, op. cit.. s. 2000. Należy dodać. że z uj̨̣ciem wojny jako rzeźni kojarzy siç z wspomnianc stowo hacken (rąbać, sickać), np. Hackfleisch (sickane mięso). Hackmessér (nóż do sickannia, np. mięsa). Hacikholz, Hackstock (pniak do rąbania mięsa lub drzewa) itp.

${ }^{7+}$ W kontckścic cytowancj wypowiedzi slowo groß jest synonimem wyrazu stol (dumnic, wyniośle, pretensjonalnic).

${ }^{75}$ Wspomniana ironia wyczuwalna jest równicż w utworze I Ierberta Żotuiers, w którym zostal sparodiowany westernowy mit wojenny. Jest to opowieśé o wyrtuszającym na wojnç żolnierzu, którego atrybutani są: szabla, ostrogi, a takżc kapclusz z piórami. W czasic drogi udaje mu sięc stać siç posiadaczem konia. Ów „bolater" wojenny - przypominający ulana - handlowal po drodze piórani, symbolizującymi wojenne zwycięstwa. Sama wojna w utworze została skoncntowana: . To waśnic byla wojna. O sprawę najważnicjszą. Czy sztandary mają być szyte z purpurowego czy też z nicbieskicgo jedwabiı" (Hpig, s. 153). Th Zatem chodzi tutaj o postać heroiczną, która - w przeciwieństwic do ludzi zwyczajnych, ukazywanych w codzicnnych sytuacjach ma przyklad przez Białoszewskiego - jest mocno stypizowana i funkcjontyc wylącznic w mitycznych wyobrazeniach wojny. Jcj prototypami byli bohaterzy romantyczni. jak Gistaw z III części Dziadón' Mickicwicza czy tytulowy bohater Kordiuna Slowackicgo (zob. M. Janion. op. cit..

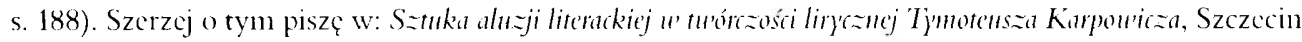
2001, s. 86-87 (Mity'uojeme).

${ }_{77}$ Z wypowiedzi Jekutsch wynika, że I Ierbert polemizuje równicz z mitem określonym przez Janion (op. cit.) jako ,romantyczny western ulański“.

7s Tacy bohaterowic znani sa z „westernowego ujęcia wojny” (M. Janion, op. cit., s. 196). Z oryginalu i przckladı wynika, żc życic czlowicka w zgodzic z naturą jest najwiçkszą wartością.
} 
cu humanizm I Jerberta — pisze Jerzy Kwiatkowski — nie jest „humanizmem mitotwórczym. I jakkolwiek poeta nawraca jeszcze niejednokrotnie do tematów wojennych - nie ma tu herosów martyrologii" ${ }^{79}$. Przez rezygnację z szukania słownych ekwiwalentów dla występujących w przekładanym lirykı jednostek leksykalnych i nagromadzenie słownictwa mieszczącego się w polu znaczeniowym „ziemi”, z którą — wynika z przejmującego wiersza Ierberta - zostają „zrównani” polegli w walce żohnierze, jak „strubkorn” (ziarnko pyłku) zamiast: Knopf (guzik), ,stäubchen” (pyłki) zamiast: Kn̈̈pfe (guziki) albo „Heidesand” (piasek na wrzosowisku) zamiast: Heide (wrzosowisko), kreuje obraz mogily, przeznaczonej dla poległych żohnierzy. Wskazana wyżej immutacja nie pozwala oddać specyficznych znaczeń, znanych polskiemu czytelnikowi, który bez trudu skojarzy słowa podmiotu lirycznego w utworze Herberta: „w ódz podnosił brwi / jak buław ç/skandowa 1: a n i guzik a” (Sś, s. 8 - moje podkr. K. K.) z legendarnym hasłem marszałka Rydza-Śmigłego, zapewniającego zaraz po wybuchu wojny, że walczący żołnierze nie oddadzą Niemcom ani jednego guzika od munduru ${ }^{80}$. Jöhling nie daje jednak szansy adresatowi przekladu na takie właśnie odczytanie przytoczonego tutaj fragmentu monologu lirycznego. Pomija — nie jest wykluczone, że celowo - występujące w literackim pierwowzorze nawiązanie do wspomnianego hasła, bowiem zastępuje poetycką metaforę I Ierberta, generującą obraz guzików, przyszytych do wrzosowisk, metaforą - przytaczam określenie Jekutsch — konwencjonalną, przedstawiającą piasek na wrzosowisku ${ }^{81}$, którym zasypane są lıdzkie zwłoki. Zostaje przez to oddana — w oslabionej formie - niezgodność między patetycznymi hasłami, nawohıjącymi do walki z wrogiem i zwiastıjącymi zwycięstwo, a losem poległych zolnierzy (UJZH, s. 189).

\footnotetext{
"J. Kwiatkowski, Imioma prostoty'. op. cit.

"Do wspomnianego hasła nawiązuje I Ierbert równicz w wierszu Guziki z tomu Rorigo (Wroclaw 1992, s. 21). poświçconym pamięci kapitana Edwarda Herberta, ojca pocty. także przełożonym przez Klausa Stacmmlera (HCV. s. 26) - wierszu, w którym motywy znane z liryku Pozégnanie u'rzésnia: „guziki”, .ppiçdź zicmi”, nawiązujące do okrzyku marszalka Rydza-Śmiglego, zostaly potraktowane z podobną ironią: „Tỵlko guziki nicugiçte / przetrwały śmicré świadkowic zbrodni / z glçbi wychodzą na powierzchuiç / jedyny pomnik wa ich grobie // są aby świadczyć Bóg policzy / i ulituje się nad nimi / lecz jak zmartwychwstać mają ciatem / kicdy są lepką cząstką ziemi”.

*I Warto zwrócić uwag̨̧, że w nicmicckicj komunikacji jçzykowej funkcjonują zwroty określające gotowość do walki w obronie ojczyzny, takic jak: Ilir geben keinen Zentineter Bodenpreis albo den Bodenpreis bis

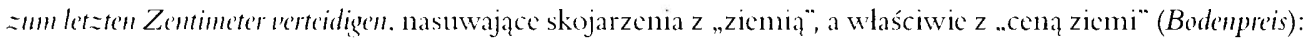
mider cinen jungen / flach eingebette' im lie idesand (ZHPa, s. 27). Wobec tego wynikająca z oryginalu myśl, że walczący zohnicrze nic chea ginąć za Ojczyznę, staje siç bardzicj wyrazista.
} 


\section{Podsumowanie}

Analizowane tutaj tlumaczenia — odznaczające się walorani artystycznymi ${ }^{\text {22 }}$ — można uznać za reprezenta cje oryginałów, minno ze Dedecius — dowodziłan - stanął po stronie poety, a Jöhling adresata przekładu, i co więcej: „kochankowi polskich nuız ${ }^{83}$ udało się - poprzez rezygnację z dostowności i znalezienie odpowiednich jednostek leksykalnych, które zastępują polskie slowa, odnaleźć też kompromis między autorem a czytelnikiem ${ }^{\text {st }}$. Przypuszczalnie Dedecius miał tego świadomość, skoro publikował omawiany przekład w różnych antologiach. Różnice między debiutancką a drugą oraz następnymi, coraz lepszymi wersjami przekładu, pozwalają zorientować się, że tłumacz w pierwszej z nich, pochodzącej z 1959 roku, jest .,sprawiedliwy wobec poszczególnych słów i zdań" (ưortgetretu), a w następnych odchodzi od dosłowności. Tworzy ponury obraz świata, który jest znakiem ikonicznym oryginalnego wizerunku poetyckiego. Bardzo ostrożnie dobiera środki artystyczne, mające za zadanie naśl a dowa ć poetykę przekladanego utworu. Unika słów odznaczających się wię̧kszą mocą illokucyjną niż zastępowane przez nie jednostki leksykalne. W ten sposób dąży do tego, aby oddać cichą i delikatną intonację utworu. Jest przecież — jak sam podkreślał — wrażliwy na brzmienie frazy poetyckiej ${ }^{45}$. Celowo wykorzystıje metodę detrakcji, a jednocześnie rezygnuje z adiekcji, którą chętnie stosował w przekładach prozy poetyckiej Herberta z tomu Hermes, pies i gu'iazda ${ }^{86}$. Zatem nie chce dopuścić do przeinterpretowania utworu. Starannie dobiera jednostki leksykalne, wyrażenia i zwroty. Za ich pomocą udaje mu się oddać sens i lic e ncję poetycką oryginalu.

Jöhling unika - w znacznie większym stopniu niż jego poprzednik - dosłownego tłumaczenia następujących po sobie słów i zdań oraz wykazuje się imponującą odwagą w dokonywanych przez niego wyborach. W przeciwieństwie do 1)edeciusa dokonuje w wierszu podziału stroficznego, który znacznie różni się od oryginalnego. Kreuje także - dowodzilam - inne obrazy niż Herbert. które w mniejszym stopniu niż wizerunki poctyckie Dedeciusa reprezentıją oryginal. Uczestnicząc w grze między autorem a adresatem przekładı, staje po stronie tego drugiego. Mimo że nie oddaje wszystkich sensów, wynika-

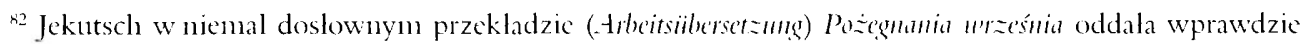
obecne tam nawiązania do polskich tradycji patriotycznych, ale jej .robocze tlumaczenic" - w przeciwieństwie do przekladu Jölılinga — pozbawione jest walorów artystycznych: „.Die Tagé u'aren amaranthfar-

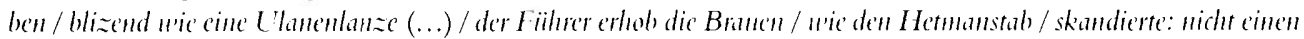

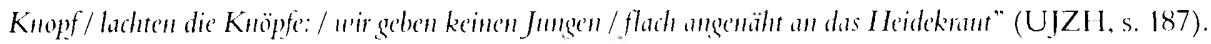

".3 Tak nazwal I Dedeciusa Egon Naganowski (zob. idem, Kodhanek polskidh muz, wst. do: K. Dedecius, Polacy' i Nicmcy.... op. cit.. s. 5-18).

${ }^{8+}$ Zob. DPR, s. 591-592: por. z OFLM, s. 180-189.

"Dedecius pisze: "Antologie’” są bliskic nemu syunfonicznemu pojmowaniu świata. Shucham wiersza jak grającej orkiestry i nic chcialbym nic uslyszé żadnego ze skladających się na nią instrumentów" (M. Crr. v. Döhnhloff, wst. do: K. Dedecius, Ost-llést Basar. op. cit.. s. 2). Pisząc te slowa, Dedecius miat na nyyśli wydawanc przez nicgo antologic przckladów wicrszy polskich poctów.

${ }^{*}$ Zoh. Z. Herbert, Mys kościdma, w: idem, Studium przedmiom, Warszawa 1964, s. 72 (dalej cyt.: Sp); idem, Die

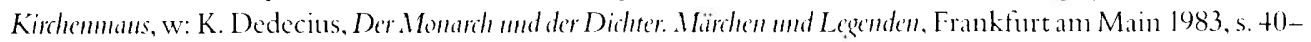
-41 (dalcj cyt.: DMD); idem, Bajka ruska (I Ipig, s. 172); idem, Russisches Märchen (DMD, s. +2; I ICV, s. 6()). 
jących z literackiego pierwowzoru, tworzy jednak wizję poetycką, która przybliza czytelnikowi wojnę, widzianą z perspektywy narodu skrzywdzonego przez niemieckich faszystów. Nie naśladuje także chłodnego, informacyjnego stylu poety. Uzupełnia „miejsca niedookreślenia" ${ }^{\mu>7}$ w utworze I Ierberta przez wspomniane zmiany w zakresie składni. W ten sposób daje świadectwo wlasnej interpretacji utworu. Potrafi wyrazić - w nieco „osłabiony" sposób (!) - ironię, którą wyczuwa się w liryku autora Napisı. Nie oddaje jednak obecnych w oryginale nawiązań do polskich tradycji patriotycznych. Być może, iż w wierszach autora Strumy'súriatla ich nie dostrzega. Nie da się jednak wykluczyć, że celowo je eliminuje, ponieważ clice $w$ ten sposób pokazać H lerberta jako poetę un iwe rs al ne go. Zwraca uwage - niczym Georg Trakl ${ }^{\text {š }}$ - na problemy moralne związane z wojną.

Zdaniem Jekutsch - jak wcześniej sugerowałam - Herbert jest prezentowany w tomie Poesieallum 86, z którego pochodzą analizowane tutaj przekłady, jako „poeta socjalistyczny” $\left(\right.$ UJZH, s. 185) ${ }^{\text {s') }}$. Powszechnie wiadomo, ze recepcja liryki polskicj w Niemczech Wschodnich ,była podporządkowana politycznej koniunkturze i układom”, panującym w naszym kraju (UJZI I, s. 181, przyp. 40). Na Polskę - pisze Olschowsky - patrzono tam

\footnotetext{
*- Micjsca niedookreślenia rozumiane są tutaj tak. jak proponuje Ingarden (Dzieto literackie i jego konkrety a acje, w: idem. O d:iele literackim.... op. cit.. s. 415-437). Por. z: L. Brogowski, Struktura konkretności i micjsca micdookreślemin "Ingardenu, .Teksty Drugie" 1993, ur 3 (21), s. 65. Przywolany filozof uważa czytchika za .wykonawcę" dzicła literackiego. które podlega czytelniczej konkretyzacji (zob. M. Glowiński. O konkret) akjii, op. cit., s. 114).

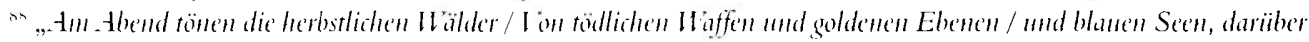

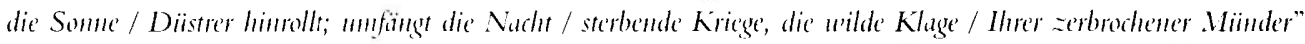
(G. Trakl. Grodek, cyt. za: 1000 Dewtsche Gedichte und ilue Interpretutione'n. Ion Georg Trakl bis Gotffiried Bemn, wyd. M. Reich-Ranicki, t. 6. Frankfurt an Main-Leipzig 1994. s. 355).

${ }^{*}$ Przywolany tutaj tom (ZH IPa) zawicra równicz — oprócz analizowancgo w ninicjszym artykule thumaczenia

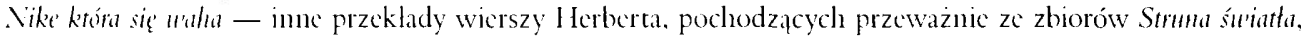
Sundium precdmiotu oraz Hermes, pies i gu'ilazda. dokonane przez Dedeciusa, thumacza zachodnionicmieckiego, na

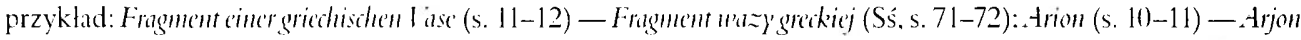
(Sś. s. 81-82): Apollo and Marsyas (s. 6-7) - Apollo i Marsias (Sp. s. 17); Fortimbras Klage (s. 12-14) - Tru Foryubrasa (Sp. s. H+-t5): Kiesel (s. 3) - Kamp'k (Sp, s. 59): Klapper (s. 31) - Kotutka (Hpig. s. 32). We wskazanych przckladach Herbert zostaje ukazany jako filuzof. klasyk i moralista. W tomic zawarte są - oprócz utworów, nawiązujących do mitologii greckiego antyku - przclożone przez Dedeciusa wiersze z motywami polskimi, jak powrót do mitu dzicciństwa i rodziców: Mein lister (s. 24) - Mój ojciec (Sś, s. 20) - oraz do wojny i okupacji: Dic

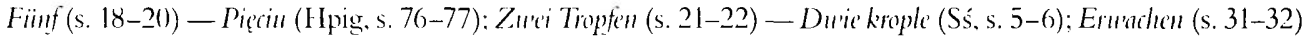

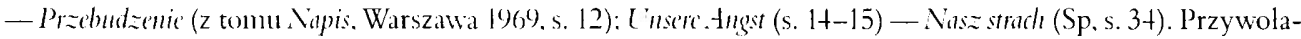
ne liryki - w których występują odwołania do lat 1939-19+5 - nic zawierajajawnych aluzji do polskich tradycji patriotycznych. Mogly zostać odczytanc przez oby watcli NRD jako wiersze wylącznie pacyf istyczne, w których zostal wyrażony protest przceciwko faszyzmowi. Wlaśnic w NRI) - pisze Olschowsky - „nic należało mówić publicznic o nicnawiści Polaków do Niemców po wojnic (...). Uważnic śledzono polskic utwory o problematyce okupacji i wojny" (Olschowsky. Idcologican' w'zore odbioru, op. cit., s. 53. 5-).
} 
jak na twór pozbawiony historii i pannięci (...). Stawiano (...) w centrum uwagi nie sąsiedni naród z tysiącletnią historią i kulturą, a tylko jego przyııleżność do wspólnego systemu politycznego"(1).

Wydawnictwa NRD-owskie publikowaly jednak niemicckic przekłady polskich dziel, ıkazıjące walkę z faszyzmem, ponieważ naród sąsiedzki — pisal Erpenbeck -

w większości swojej (w przeciwieństwie do naszego) świadomy swych celów prowadzil aktywną walkę przeciw faszyzmowi i w tej walce zwyciçżyl"

Z cytowanej tutaj wypowiedzi można bez trudu wyprowadzić ówczesny, bardzo prosty wzorzec rozumowania: ,jedynie słusznym spełnieniem posłania przeciwników faszyzınu jest aktywne uczestnictwo w budowie socjalizmu"') 2. Po odniesieniu tego wzorca do przekładı Jöhlinga automatycznie nasuwa się wniosek: skoro I lerbert jest antyfaszystą, to znaczy, że akceptuje ustrój socjalistyczny. Thumacz dowodzi jednak, że postrzega poetę - tak jak Dedecius - jako moralis tę, stojącego po stronic pokrzywdzonych. Autor Ost-IVest Basar wypowiada się na ten temat expressis verhis: „Herbert uosabia (...) filozoficzny sceptycyzm współczesnego moralisty" (PPJ, s. 213).

\footnotetext{
Ibidem, s. 5 t.

"F. Erpenbeck. "Neues 1)eutschland" 1 XI 1949, s. 2; por. I I. Olschowsky, op. cit., s. 56.

"H. Olschowsky, op. cit.
} 